\title{
The Application of the Constitutional Convention in Malaysia
}

\author{
Nazri Muslim ${ }^{1}$, Osman Md Rasip ${ }^{2}$, Khairul Hamimah Mohammad Jodi ${ }^{3}$, Abdullah Ibrahim ${ }^{4} \&$ Otong Rosadi $^{5}$ \\ ${ }^{1}$ Pusat Citra, Universiti Kebangsaan Malaysia, Malaysia \\ ${ }^{2}$ Academy of Islamic Studies, Universiti Malaya, Malaysia \\ ${ }^{3}$ Education and Social Science Cluster, Open University Malaysia, Malaysia \\ ${ }^{4}$ Center of Core Studies, Universiti Sultan Zainal Abidin, Malaysia \\ ${ }^{5}$ Universitas Ekasakti, Indonesia \\ Correspondence: Nazri Muslim, Pusat Citra, Universiti Kebangsaan Malaysia, Bangi, Selangor, Malaysia. Tel: \\ 03-8-8921-6915. E-mail: nazrim@ukm.edu.my
}

Received: April 10, 2020

doi:10.5539/jpl.v13n2p155
Accepted: May 9, $2020 \quad$ Online Published: May 25, 2020

URL: https://doi.org/10.5539/jpl.v13n2p155

\begin{abstract}
In Malaysia, there is no one institution that can outdo the supremacy of the Federal Constitution. Even the three government bodies that refer to the power separation doctrine which is the legislative, judiciary and executive bodies even the Yang di-Pertuan Agong are under this Federal Constitution. The constitution can be divided into two, written and non-written constitution. The written constitution is the form of constitution that is gathered and arranged in one document. The non-written counterpart encompasses all of the constitutional principles not compiled in one document such as the law endorsed by the Parliament and the verdicts of the court such as in the United Kingdom. Other than the constitution, there are certain practices that are thought to be part of the principles of the constitution. This is known as the Constitutional Convention or the customary practice of the Constitution. Constitutional convention is a non-legislative practice and it is similar to the political ethics and not enforced in court. Although it seems trivial, it is important for this practice to be complied with, otherwise it is difficult for the constitution to work successfully as the constitutional convention cannot be brought to court and forced to be obeyed. Thus, the discussion of this article rests on the constitutional convention in terms of the social contract, the appointment of the Prime Minister, the appointment of the country's main positions and collective responsibility.
\end{abstract}

Keywords: constitutional convention, federal constitution, social contract, collective responsibility, Malay

\section{Introduction}

For a sovereign country like Malaysia, the constitution is the highest legislative source and every citizen must honour and obey its excellency as dictated in the third National Principle which is The Supremacy Of The Constitution. Its existence serves to arrange and coordinate a country's administration and ruling. Apart from that, the constitution also plays the role as a guideline for the formation of the law, be it for the government, the people or anyone at all. Constitutional conventions are basically customs, habits and/or common practices that regulate the conduct of parliament, the government and the courts. Notwithstanding the fact that conventions do not possess the force of law (considering that the courts do not enforce them), they are still part of the Federal Constitution since these practices are considered "law" under Article 160(1). As political practices, the flexibility and evolution provided by constitutional conventions reflect the local realities of the day. Unlike written laws, constitutional conventions may be unilaterally altered by the government of the day without going through any formalities. The constitution can be divided into two, written and non-written constitution. The written constitution is the form of constitution that is gathered and arranged in one document. The non-written counterpart encompasses all of the constitutional principles not compiled in one document such as the law endorsed by the Parliament and the verdicts of the court such as in the United Kingdom. Other than the constitution, there are certain practices that are thought to be part of the principles of the constitution. This is known as the Constitutional Convention or the customary practice of the Constitution. Constitutional convention is a non-legislative practice and it is similar to the political ethics and not enforced in court. Although it seems trivial, it is important for this practice to be complied with, otherwise it is difficult for the constitution to work successfully as the constitutional convention cannot be brought to court and forced to be obeyed. 


\section{Structure Government of Malaysia}

The Government of Malaysia officially the Federal Government of Malaysia is based in the Federal Territory of Putrajaya with the exception of the legislative branch, which is based in the national capital of Kuala Lumpur. Malaysia is a federation of 13 states operating within a constitutional monarchy under the Westminster parliamentary system and is categorised as a representative democracy. The federal government of Malaysia adheres to and is created by the Federal Constitution of Malaysia, the supreme law of the land.

The federal government adopts the principle of separation of powers under Article 127 of the Federal Constitution, and has three branches: executive, legislature and judiciary. The state governments in Malaysia also have their respective executive and legislative bodies. The judicial system in Malaysia is a federalised court system operating uniformly throughout the country. The federal or central government is the ultimate authority in Malaysia and located in Putrajaya. It is headed by the Prime Minister of Malaysia who is also known as the head of government.

The bicameral parliament consists of the lower house, the House of Representatives or Dewan Rakyat and the upper house, the Senate or Dewan Negara. All seventy Senate members sit for three-year terms (to a maximum of two terms); twenty-six are elected by the thirteen state assemblies, and forty-four are appointed by the king based on the advice of the Prime Minister. The 222 members of the Dewan Rakyat are elected from single-member districts by universal adult suffrage. The parliament follows a multi-party system and the governing body is elected through a first-past-the-post system. Parliament has a maximum mandate of five years by law. The king may dissolve parliament at any time and usually does so upon the advice of the Prime Minister.

While the Monarch remains the Head of State real executive power is vested in the cabinet led by the prime minister as Head of Government; the Malaysian constitution stipulates that the prime minister must be a member of the Lower House of parliament who, in the opinion of the Yang di-Pertuan Agong, commands a majority in parliament. The cabinet is chosen from among members of both houses of Parliament and is responsible to that body. The Executive branch of the government consists of the Prime Minister as the head of the government, followed by the various ministers of the Cabinet.

The Cabinet of Malaysia is the executive branch of Malaysia's government. Led by the Prime Minister, the cabinet is a council of ministers who are accountable collectively to the Parliament. According to the Article 43 of the Constitution, members of the Cabinet can only be selected from members of either houses of Parliament. Formally, the Yang di-Pertuan Agong appoints all Ministers on the advice of the Prime Minister. The constitution is amended by repealing the Clause (8) of Article 43, enabling a person who is a member of State Legislative Assembly to continue to be one even when he or she is appointed as a minister or deputy minister in the cabinet. Ministers other than the Prime Minister shall hold office during the pleasure of the Yang di-Pertuan Agong, unless the appointment of any Minister shall have been revoked by the Yang di-Pertuan Agong on the advice of the Prime Minister but any Minister may resign his office. In practice, the Yang di-Pertuan Agong is obliged to follow the advice of the Prime Minister on the appointment and dismissal of ministers.

The highest court in the judicial system is the Federal Court, followed by the Court of Appeal, and two High Courts, one for Peninsular Malaysia, and one for East Malaysia. The subordinate courts in each of these jurisdictions include Sessions Courts, Magistrates' Courts, and Courts for Children. Malaysia also has a Special Court to hear cases brought by or against all Royalty. There are generally two types of trials, criminal and civil. The hierarchy of courts begins from the Magistrates' Court, Sessions Court, High Court, Court of Appeal, and finally, the Federal Court. The jurisdiction of the courts in civil or criminal matters are contained in the Subordinate Courts Act 1948 and the Courts of Judicature Act 1964. Article 121 of the Constitution provides for two High Courts of co-ordinate jurisdiction, the High Court in Malaya, and the High Court in Sabah and Sarawak. Thus this creates two separate local jurisdiction of the courts - for Peninsular Malaysia and for East Malaysia. The highest position in the judiciary of Malaysia is the Chief Justice of the Federal Court of Malaysia (also known as the Chief Justice of Malaysia), followed by the President of the Court of Appeal, the Chief Judge of Malaya, and the Chief Judge of Sabah and Sarawak. The superior courts are the High Court, Court of Appeal, and the Federal Court, while the Magistrates' Courts and the Sessions Courts are classified as subordinate courts.

\section{History of the Federal Constitution}

In Malaysia, no institution can outperform the supremacy of the Federal Constitution. The three government bodies referring to the power separation doctrine which is the legislative, judiciary and executive bodies and even the Yang di-Pertuan Agong are bound to the Federal Constitution (Harding 2002). For example, the law of the legislation must be executed to the restrictions imposed by the constitution. Even the federal law or the state law about a particular issue can be declared as invalid by the court if the law contradicts the Federal Constitution. 
This is because the constitution has allocated clearly under Article 4(1) that the constitution is the main federal law and any law endorsed post-independence and which opposes the constitution must be considered void.

The basis of this Federal Constitution started with the declaration of the Malayan Federal Constitution on 1st February 1948. According to this constitution, a British High Commissioner is placed under the Central Government as the highest ruler (Mohamad Sufian Hashim 1987). The local citizens are represented through the Meeting Council and the Legislative Council in preparation for self-government. Thus, when the Alliance won the 1955 General Election by taking over 51 from the 52 seats contested, a conference was held in London from 18th January to $6^{\text {th }}$ February 1956. As a result, a commission named Reid Commission was formed to formulate a new constitution for the free and independent Federation of Malaya.

The Federal Constitution of Malaya was the brainchild of the Reid Commission established in 1956. This commission was led by Lord Reid and it received 131 written memorandum and they had convened from June to October 1956. This constitution became strong, practical and respectable as it had asked for the suggestions and opinions from not only the political parties but also the general public, individuals and Malay Kings and Sultans at the time (Harding \& Lee 2007). This justifies the fact that the current Federal Constitution has been endorsed and agreed by all layers of the citizens of Malaya.

When formulating the constitution, the Malays and the non-Malays agreed on several matters that are very important to the country's stability in reference to the social contract. Through this social contract, the non-Malays are given the lenient right of citizenship based on the principle of jus soli. Meanwhile, the Malays are allocated in the constitution in terms of Islam as the federal religion, Malay Language as the national language and the special position of the Malays and the position of the Malay kings or what we call the elements of tradition in the constitution (Nazri Muslim and Azizi Umar 2017). The Royal Council has given an official agreement towards the draft of the Federal Constitution on 27 June 1957. The draft was then approved anonymously by all the representatives in the Federal Assembly Board on $11^{\text {th }}$ July 1957 . The consensus enabled Malaya to obtain its independence on the 31 August 1957 (Abdul Halim Ramli, 2015).

The formation of Malaysia in 1963 gives another dimension to the ethnic relations in Malaysia (Nazri Muslim et. al. 2015). With the entry of Sabah and Sarawak, the position of Bumiputera ethnics in both the states is given the same status as the Malays, where they are also included in Article Perkara 153. However, the allocation does not give the ticket to oppress other races because the special privilege of the Malays and Sabah and Sarawak Bumiputera has to be protected by means of not denying the validity of the position. The Malaysian Agreement sealed in 1963 is one of the agreements that have been mutually agreed upon by leaders of Malaya, Sabah and Sarawak. It is known as Perkara Dua Puluh or Perkara Lapan Belas containing the demands made by Sabah and Sarawak that agreed to join Malaysia. Some of the contents include immigration, language, finance and the special rights of the Sabah and Sarawak Bumiputera. It can be referred in List II and List III and related to the additional allocation for Sabah and Sarawak. Both states' position in the constitution is protected by the power of the States' Yang di Pertua, whereby the amendment can only be made if they gave their agreement. This means that the parliament cannot amend the special position of Sabah and Sarawak Bumiputera. This resembles the role and the power of the Royal Council in relation to the position of the Malays (Nazri Muslim et. al. 2019).

The constitution can be divided into two, which is written and non-written constitution. The written constitution is the form of constitution collected and arranged in a document. Meanwhile the non-written constitution encompasses all principles of the constitution not compiled in a document such as the Bill passed by the parliament and court's verdicts like the United Kingdom. The constitution can be found in various acts of the parliament, court's verdicts, constitutional convention and the opinion and view of the figures known in the field of legislation. According to Mohd Salleh Abas (1984), the written constitution has three characteristics. The first one is that this constitution is rigid and difficult to amend unless there is an allocation in the constitution that enables such an allocation to be made. If an amendment has to be made, we need to obey and follow the procedure through consensus or majority of votes in the Parliament. However, for the non-written constitution, the change in the constitution came by itself because the amendment came gradually due to the change in the customs of the constitution. Secondly, with regard to the parliamentary authority that only has the power in making the law in matters contained in the constitution. Thirdly, it is about the duties of the court. As the constitution is written, it is imperative that the constitution gets the right interpretation, and that it is clear and finalised.

For Wheare (1980), the constitution can be classified into five namely:

1) Written and non-written constitution.

2) Flexible and rigid constitution. 
3) High and low constitution.

4) Federal Constitution and the board constitution.

5) The presidential constitution and parliamentary constitution

This classification by Wheare is wider with reference to the ruling system of a country, other than touching on the concept of the constitutional supremacy (Nazri Muslim 2014).

According to Wheare, there are three possibilities of task distribution in the Constitution which is:

1) In the constitution in detail and covering the jurisdiction of the federation, whereas the rest is under the state.

2) In the constitution laid out in detail covering the power of the state, whereas the rest is under the federal jurisdiction.

3) In the constitution, there is the federal jurisdiction and the state respectively explained in detail and comprehensive. (Otong Rosadi, 2015)

Meanwhile the amendment towards the Federal Constitution can be done through the following conditions:

1) Article 159 (4) explains that some of the items that can be amended require the support of more than $2 / 3$ members of the House such as loyalty oath, the selection and pension of members of the Senate.

2) Article 161 (E) explains that some of the items can be amended, where they can get the 2/3 support of every House and this is agreed by the Yang di-Pertua of Sabah and Sarawak to involve the interests of Sabah and Sarawak such as the jurisdiction of the state government and the special position of Bumiputera.

3) Article 159 (5) explains that 2/3 support from every member of the House and the endorsement of the Royal Council must be obtained, involving items like the sovereignty of the kings, the special position of the Malays, Sabah and Sarawak Bumiputera, the national language and the federal religion.

\section{The Concept of the Constitutional Convention}

Other than the constitution, there is certain practice that becomes part of the principles of the constitution. This practice is known as the Constitutional convention or the custom of the Constitution. According to Dicey (1959), the constitutional convention is the non-legislative practice which resembles political ethics and will not be enforced by the court. This practice is very important because if this practice is violated, the constitution will be affected. This is because the practice cannot be brought to court and imposed upon. Constitutional convention does not have any legislative effect if there is a violation on it. The constitutional convention is also a positive morality practice of the constitution that binds the party to it, but this practice is not the law that can be enforced. There is no party that is allowed to take a legal action if there is a violation by any party and it is within the interest of the government to make sure that the convention is obeyed and respected by all parties.

According to Bagir Manan (1987), constitutional convention in an Indonesian term is known as konvensi or nationhood- it is the law that grows in the practice of the government to complete, facilitate, dynamist the methods of legislation or the laws of nationhood. Operationally speaking, the nationhood convention can be defined as the normality in the nationhood practice that should be repeated and obeyed.

Constitutional convention has been applied in Malaysia for a long time when this country agreed to use the parliamentary democratic monarchy system as practised in Britain. All the conventions applied in Westminster is generally applicable to Malaysia (Rusniah Ahmad 2008). Additionally, Malaysia practices federalism, thus the convention also needs to be respected at the central and state levels. This is something unique because the rulers at state level might have a different political ideology from those at central level. A number of general election results have shown this difference in ideology between the state and central governments. The same goes with the power transfer of the central government that happened in Malaysia during the $14^{\text {th }}$ general election.

The constitutional convention is a significant issue and worth researching since it is a very live issue and plays a vital role in the British constitution. A variety of names has been called to these non-legal rules of constitutional conduct such as 'practice', 'customs', and 'conventions'. These lists of rules are not easy to tell from what might be called as 'principle', 'tradition' or 'doctrine'. The initial research showed that the issue of constitutional conventions raised by Dicey (1959) in Introduction to the Study of the Law of the Constitution still poses many unanswered questions and that it has been raised by several important cases heard in the England courts as well as in other jurisdictions.

The doctrine of constitutional convention is a crucial premise of any political and legal systems in the world: in 
United Kingdom culture sovereignty of a nation is considered one of its most precious values. Therefore, knowing that it could be limited for the benefit of some governments, organisations or courts might be difficult to accept. Conventions in the context of constitutional law have a special meaning - the government's actions limit their power in order to strengthen the true value of democracy. However, it also still signifies important rules and practices and as such remains a precious value for the nation. The imbalance between pursuit of codifying conventions and unwritten constitution may lead to many difficulties in the future.

Dicey (1959) selected out a number of rules as within the constitutional conventions. These include the rules of the monarch appoints the leader of the majority party who gained a majority command of House of Commons; government must resign if defeated on a vote of no confidence. Indeed, back in 1979, the Labour government Prime Minister Mr James Callaghan lost a vote of confidence and dissolved the Parliament which was granted.

House of Lords members must be politically neutral and avoid from involve in party political debate; and the ministers must resign if found any mismanagement of their departments. Then the research found the decisions of Supreme Court of Canada and Queens' Bench Decision (QBD) in the case of Attorney-General v Jonathan Cape Ltd were a significant steps in the discussion of this issue and had deepen the understandings of the topic. Then this essay explains the important and relevance statute and legal cases. Then it explores what problems it causes and whether this law has been applied correctly or justly. Follow by the appreciation of comments on the consistency of the law. This essay also offers reasons from views of selected authors by adopting one of the perspectives with limited further justification. And lastly, the final part will be a conclusion.

A starting point will therefore be an analysis and the content and essence of the principals of characteristics of the constitution and constitutional convention. United Kingdom is a unique system with unwritten constitution. As far as the system of government is concern, there is no organization or political party is never making mistakes nor has an absolute monopoly of wisdom. The government in power should be democratically and legally accountable and that they should promote good governance in the public interest rather than in their personal interests or within their group or particular selected people of society. Any actions by the government are answerable to the courts of law and to Parliament.

In addition, United Kingdom unwritten constitution is also flexible compares to written constitution such as Malaysia and United States. Up to a certain extent, it is a constitutional monarchy where by convention the powers of the Queen are exercised by the appointed ministers of government. These ministers are required to seat in either Houses of Parliament. But, because of the House of Commons is an elected chamber and dominant, the ministers actually seat in the lower House. Ministers are subject to judicial review when they exercised statutory powers and royal prerogative powers because these powers are subject to parliamentary and judicial control then it can be said constitutional.

The prerogative powers of the monarch are by convention must appoint ministers from among members of Parliament. And, it also requires the crown to appoint the Prime Minister and the Chancellor of Exchequer to seat as members of the House of Commons. From these appointments of the Prime Minister and the Chancellor of Exchequer, the provisions of the Parliament Acts 1911 and 1949 give primacy that Money Bill and all Bills must originate from the House of Commons and any Bills passed from this House will receive royal assent and the Queen cannot veto against the Bills. By the same token, even the House of Lords also cannot refuse or reject the Bills. The purpose of these because the members of House of Commons are elected while those from upper House are hereditary peers or being appointed.

The conventional rule also protects the independence of the judiciary especially the superior judges. The conducts of judges are not answerable in the lower House unless there is a substantive issue motion before the House. On top of that, it is a convention that the speaker of the lower House must be impartial and give fair chances to all parties. In UK, the Speaker is chosen from the opposition party and Malaysia for instance is elected from the government. The Speaker can retain office even though the government resign and ceases to hold office.

In Australian history, the term Constitutional Convention refers to four distinct gatherings. The 1891 Constitutional Convention was held in Sydney in March 1891 to consider a draft Constitution for the proposed federation of the British colonies in Australia and New Zealand. There were 46 delegates at the Convention, chosen by the seven colonial parliaments. Among the delegates was Sir Henry Parkes, known as the "Father of Federation". The next constitutional convention - the Australasian Federal Convention - was held in stages in 1897-98. Unlike the first convention, the delegates were elected by popular vote. It met first in Adelaide in March 1897, secondly in Sydney in August, and thirdly in Melbourne in the sweltering heat of January 1898. The intervals between the sessions were used for intense debate in the colonial parliaments and for public 
discussion of the draft constitution (Williams, John M. 2005).

Since 1891 New Zealand had lost interest in federating with the Australian colonies, and was not represented. In Queensland, the parliament had not passed the necessary legislation, so the northern colony was also unrepresented. In the other five colonies ten delegates from each colony were elected by the people, although Western Australian attendance was sporadic. At Melbourne the convention finally produced a draft constitution which was eventually approved by the people at referendums in the colonies.

The 1973 Constitutional Convention was established by the Whitlam government in 1973 to consider possible amendments to the Constitution which could be put to the people for approval at a referendum. The Convention, which was not elected but consisted of delegates chosen by the federal and state Parliaments, met through 197375 but was mired in the partisan atmosphere of the Whitlam years and achieved nothing.

The 1998 Constitutional Convention met in Canberra in February 1998. The Convention was convened by Prime Minister John Howard to fulfill a promise made by his predecessor as Liberal leader, Alexander Downer. During the Convention, Prime Minister John Howard dedicated an area of parkland to the south-east of Old Parliament House as Constitution Place, Canberra.

The Convention consisted of 152 delegates, of whom half were elected by the people and half were appointed by the federal government. This latter group included senior federal, state and territory politicians appointed by virtue of their positions.

The Convention was divided into four philosophical groups: those wanting to retain Australia's existing constitutional monarchy, those wanting Australia to become a republic with a president chosen by the Parliament ("indirect electionists"), those wanting Australia to become a republic with a president elected by the people ("direct electionists"), and those having no fixed position or seeking a compromise between the other groups. In the fourth group, Republicans dominated both subgroups, but proved far from united in their views. (La Nauze, J. A. 1972).

In Malaysia, interpreting the constitution is seen to be a priority compared to the constitutional convention. For a new country, or recently becoming independent and having little experience about the constitution, it is hard to determine if an item would be regarded as part of the constitutional convention. This is because before it became a convention, it needed to be practised a few times until an agreement among the people can be obeyed. However, after more than 61 years of independence, will the Constitutional convention be considered and understood by the Malaysians when there is an issue involving the Federal Constitution? (Nazri Muslim 2015).

Why does the convention have to be obeyed? This is because the convention has an important role to play in the political system economy and the social aspect of Malaysians. This convention is based on the political requirements because if it is violated, there will be come political adversities. Other than that, the violators will be exposed to the negative perceptions of the people causing them to lose confidence and respect.

\section{The Analysis of the Constitutional Convention in Malaysia}

There are various conventions that have become the tradition and practice in Malaysia, among which is the constitutional customs in the form of adherence to the appointment ceremony which is a mere case of formality, like the appointment of the Cabinet Ministers.

This article discusses several examples of application of the constitutional convention in Malaysia. The first one is the social contract. The social contract in Malaysia refers to the understanding made by Malaya's founding fathers in the Constitution, nearing its independence. The social contract refers to a trade-off through Articles 14-18 of the Constitution, pertaining to the granting of citizenship to the non-Bumiputera of Malaya (particularly Malaysian Chinese and Indian), and this was carried over to Article 153 when Malaysia was formed on 16 September 1963, which grants the Malays a special position in the country. This circumstance does not apply in Sarawak as all racial groups were citizens, bestowed by the legitimate Brooke government, way before the founding of Malaysia.

In its typical context related to race relations, the social contract has been heavily criticised by many, including politicians from the Barisan Nasional coalition, who contend that constant harping on the non-Malays' debt to the Malays for citizenship has alienated them from the country. The Constitution does not explicitly refer to a "social contract" (in terms of citizenship rights and privileges), and no act of law or document has ever fully set out the social contract's terms. Its defenders often refer to the Constitution as setting out the social contract, and the Malaysian founding fathers having agreed to it, although no reference to a "social contract" appears in the Constitution. Instead, the social contract is typically taken to mean a quid pro quo agreement that provides the non-Malay and other non-indigenous peoples of Malaysia (mostly the Malaysian Chinese and Malaysian Indians) 
with citizenship, in return for recognising the special position of the Malays and indigenous people of Malaysia, collectively referred to as the Bumiputra.

Social contract is an agreement not dictated in the Federal Constitution and this has been accepted by the Malays and the non-Malays. The latter accepts the special position of the former, Islam as federal religion, Malay Language as the national language and the supremacy of the royal institutions and as a reward for the Malays' openness in accepting the non-Malays as the citizens with the same right to vote and so on (Nazri Muslim 2016). This social contract is accepted by the Bumiputera and the non-Malays. They are willing to accept the privilege of the Malays and other elements as the favour returned for the native's willingness to accept them as citizens entitled for basic rights such as the right to vote and so on. However, to what extent can this agreement be accepted by the younger generation today, those born after 60 years of independence? Earlier on, the leaders' tradition and charismatic are regarded as a strong basis to build the validity of the law, but the modern society today requires the rational law in line with the change that takes place in the country (Nazri Muslim 2018).

Thus, the change or rejection of this social contract will lead to the disharmony of the Malaysians. Issues related to the Social Contract are the ones often questioned and raised by political parties especially when Malaysians are seen to be conflicting and disunited.

Secondly, there is the appointment of the Prime Minister of Malaysia. The constitution clearly states that the appointment of the Prime Minister rests on the individual who has won the election in the House of Representatives and gain the most support from members of the House of Representatives (Nazri Muslim 2018). It is not stated that the Prime Minister must be a Malay, Muslim like the appointment of the Menteri Besar for states with a king. In this current condition, where the majority of Malaysians are Malays, and they are also the original citizens of Malaya, it is hard to accept the fact that the position of Prime Minister is given to the non-Malays. However this has happened in the United States, when Barack Obama was accepted as the first non-White President of America after hundreds of years that America was led by a White.

Thirdly, the appointment of the Chief Justice, State Attorney, Brigadier General, Chief Police, State Secretary, Election Chairman and so on. Example, There is no prescription in the Constitution of the AG's race, religion, region or gender. In the past, we have had non-Muslim AGs. Except in relation to the Sultans, the Malay regiment and the Mentris Besar in the nine Malay states, the Constitution is blind to race and colour. Under Articles 8(1), 8(2) and 136, the rule of equality before the law applies. The argument by some that as the King is the head of the religion of Islam, therefore the AG must be a Muslim, is a thinly disguised attempt to misuse Islam to deprive non-Malays and non-Muslims of any place in the corridors of power. Contrary to what some religious preachers preach, Islam is perfectly capable of inclusiveness and such twisted arguments bring Islam a bad name. We have had two non-Muslim AGs before: Thomas Vernor Alexander Brodie (1955-59) and Cecil M. Sheridan (1959-63). Even the Muslim ones were not experts in Islam and they relied on their 1,800-strong team to draft opinions and laws on all matters including the syariah. As to counselling the King on matters of Islam, Article 3(5) provides that Parliament may by law constitute a Council to advise the King in matters relating to Islam. A parliamentary initiative on this matter to legalise institutions like the Malaysian Islamic Development Department (Jakim) and define their jurisdiction is necessary. As to prosecution, Article 145(3) excludes the Syariah courts from the AG's jurisdiction.

This has also become the practice of the Constitutional convention because it is difficult for the Malays in particular, to accept that the main position of the government is given to the non-Malay although the constitution clearly does not place any Malay or Muslim orientation for the appointment. This is because the position is very important for the Malays, so all the special privileges can be retained, (Nazri Muslim 2019). The appointment of the Chief Justice and State Attorney in 2018 has clearly created worry among the Malays. This issue is hotly debated in the mass media especially with regard to the authority of the Yang di-Pertuan Agong, the position of Islam, the special position of the Malays and the political erosion of the Malays that are able to raise a much greater constitutional crisis. For example, the discussion about the Yang di-Pertuan Agong involving the issue in 145 Federal Constitution only states that the power of the Yang di-Pertuan Agong to appoint someone qualified to be the State Attorney and which does not mention the role of the Royal Council, the Majesty has the role in facing this latest turmoil. However, this does not mean that the Council do not have to be concerned at all. This is because an action taken by the Yang di-Pertuan Agong will automatically leave a great impact on the entire future of the Malaysian monarchy (Nazri Muslim 2020).

The fourth one is the collective responsibility in the Malaysian Cabinet. This implies that every minister must abide by every policy and decision made by the cabinet disregarding one minister who disagrees (Rusniah Ahmad 2008). The members cannot make any open comment that can reflect his disagreement on any of the 
Cabinet's decisions, and he cannot even comment on anything yet to be decided by the cabinet, let alone if the matter is not under his Ministry, because such an action has a potential to bind the Cabinet. Thus, if a minister disagrees with the decision made by the Cabinet, the minister has to resign. This statement is not stated in any of the laws, but this collective responsibility has been accepted as part of the constitutional convention. Cabinet collective responsibility, also known as collective ministerial responsibility, is a constitutional convention in Parliamentary systems that members of the cabinet must publicly support all governmental decisions made in Cabinet, even if they do not privately agree with them. This support includes voting for the government in the legislature. Some Communist political parties apply a similar convention of democratic centralism to their central committee.

Cabinet collective responsibility is a tradition in parliamentary governments in which the prime minister is responsible for appointing the cabinet ministers. The cabinet ministers are usually selected from the same political party as the prime minister to make collective decision-making for legislation faster and more effective. Unlike a presidential system, as used, for example, in the United States, a parliamentary system's executive and legislative branches are intertwined. Because of the fusion of powers of the executive and legislative branches the prime minister relies on the cabinet to always support policy decisions. A breach of cabinet collective responsibility, such as when a cabinet member publicly disagrees with an executive decision, results in resignation or termination from the cabinet.

Parliamentary democracies such as Australia, the United Kingdom and Canada practice and adhere to cabinet collective responsibility. Rhodes, Wanna and Weller (2009) offer this description of the principle of cabinet solidarity in Westminster systems of parliamentary democracy: "Cabinet solidarity and collective responsibility are twin dimensions of responsible party government that enjoy constitutionality, albeit informally. They lie at the core of ministerial governance. Cabinet solidarity is purely a political convention designed to maintain or protect the collective good as perceived by a partisan ministry. It rests on the notion that the executive ought to appear a collective entity, able to maintain cohesion and display political strength".

In Australia, cabinet collective responsibility is fundamental to cabinet confidentiality, but also to protect private information from becoming public and possibly threatening national security. Cabinet solidarity is not a legal requirement, but a political convention and practiced norm. There is no written law that upholds cabinet collective responsibility, but it is deeply ingrained in Australia's cabinets as a political norm and is therefore an important aspect of the collective strength and influence of the prime minister's administration.

\section{Conclusion}

The people have to accept the fact that they need to accept, learn and live in the pluralistic society, of various religions and cultures. Malaysia comprises of the majority of the Malay ethnics, Chinese, Indians, Sabah and Sarawak Bumiputera also the diversity of other ethnic groups. They also embrace various religions and come from various backgrounds such as from the city and rural areas, from primary and secondary schools, follow various study programs, graduate from the universities and colleges, coming from high income, moderate income and low income groups. The diversity and differences are not the factor for separation and to be foes, but as an element to the culture of getting to know each other and helping one another so that peace and wellbeing can be achieved. Thus, every Malaysian needs to understand the concept of the Constitutional convention and they cannot simply see the Federal Constitution on the surface as the interpretation of the constitution has to be seen from the constitutional convention perspective, history, politics, social and economy. It is through this understanding that any issue related to the constitution can be well accepted by all Malaysians. The discussion in this article shows that Malaysia has adhered to the Constitutional Convention since the beginning of its independence until now. The observance of the Convention was much more evident after the 14th General Election, but there were some issues such as violating the constitutional convention. Adherence to shared responsibility in the decision of the Cabinet is seen as strongly held. However, the issue of the appointment of the Chief Justice and the Attorney General, as this convention is not observed because of the appointment of the Chief Justice and the Attorney-country national must not be practiced by the appointment of the Malays and Muslims. This situation has raised a number of constitutional issues that need to be addressed in the constitution as well.

\section{References}

Abdul, H. R. (2015). Perlembagaan Malaysia, Isu dan Persoalan Perhubungan Kaum. Kuala Lumpur: Dewan Bahasa dan Pustaka.

Bagir, M. (1987). Konvensi Ketatanegaraan. Bandung: Armico. 
Dicey, A. V. (1959). Introduction to the Study of the Constitution. UK: MacMillan.

Dicey, A. V. (1959). The Law of the Constitution (10th ed.). London: Macmillan.

Erskine May. (1989). Parliamentary Practice. UK: Lexis Nexis.

Harding, A. (2002). The Keris, the crescent and blind goddess: The state, Islam and the constitution in Malaysia. Singapore Journal of International \& Comparative Law, 6.

Harding, A., \& Lee, H. P. (2007). Constitutional Landmarks in Malaysia: The First 50 Years 1957-2007. Petaling Jaya: Malayan Law Journal Sdn. Bhd.

La Nauze, J. A. (1972). The Making of the Australian Constitution. Melbourne: Melbourne U.P.

Mohamed, S. H. (1987). Mengenal Perlembagaan Malaysia. Dewan Bahasa dan Pustaka. Kuala Lumpur.

Nazri, M. (2014). Institusi Raja-Raja Melayu: Peranannya dalam Memelihara Kedudukan Islam Dari Sudut Perlembagaan. Jurnal Antarabangsa Alam dan Tamadun Melayu, 2(2), 121-127.

Nazri, M. (2015). Level of Acceptence among Public Institution of Higher Learning towards the Institution of Malay Rulers According to Federal Constitution of Malaysia. Mediterranean Journal of Social Sciences, 6(4), 153-164.

Nazri, M. (2016). Kefahaman dan Penerimaan Belia Terhadap Perlembagaan Persekutuan Malaysia. Malaysian Journal of Youth Studies, 14, 29-54.

Nazri, M. (2017). Raja dan Rakyat Berpisah Tiada. Dewan Masyarakat. Dewan Bahasa dan Pustaka: Mac.

Nazri, M. (2018). Bagaimana Hak Istimewa Melayu Boleh Tergugat. Berita Harian, 11 Ogos.

Nazri, M. (2019). Perkasa Agenda Memasyarakatkan Perlembagaan. Berita Harian. 26 Januari.

Nazri, M. (2020). Usah Tafsir Perlembagaan. Berita Harian. 20 Januari.

Nazri, M., \& Azizi, U. (2017). Malays Royal Institution According to the Federal Constitution Within the context of Ethnic Relations In Malaysia. Akademika. 87(1), 35-48. https://doi.org/10.17576/akad-2017-8701-03

Nazri, M., Faridah, J., Nurhafilah, M., Khairil, A. M., \& Rasyikah, M. K. (2015). Malaysian Federalism - Issues and Acceptance. Australian Journal of Sustainable Business and Society, 1(1), 109-118.

Nazri, M., Wan, Z. W. H., Jamsari, A., Norazila, M., \& Abdullah, I. (2019). Malaysia federal constitution from constitutional sociology contexts. Journal of Engineering and Applied Sciences, 14(11), 3761-3770. https://doi.org/10.36478/jeasci.2019.3761.3770

Otong, R. (2015). Hukum Tata Negara: Teks dan Konteks. Yogyakarta: Deepublish.

Reference Re Amendment of the Constitution of Canada (Nos. 1, 2, and 3) (1981), 125 D.L.R (3d) 1.

Rhodes, R. A. W., Wanna, J., \& Weller, P. (2009). Comparing Westminster. London: Oxford U.P. https://doi.org/10.1093/acprof:oso/9780199563494.001.0001

Rusniah, A. (2008). Konvensi Perlembagaan: Aplikasi dan Kesan Pelanggarannya Dalam Konteks Konsep Kerajaan Terkawal. Kanun, (20), 1-11.

Wheare, K. C. (1980). Modern Constitutions (2ed. ed.). London: Oxford University Press.

Williams, J. M. (2005). The Australian Constitution: a Documentary History. Melbourne: Melbourne U.P.

\section{Copyrights}

Copyright for this article is retained by the author(s), with first publication rights granted to the journal.

This is an open-access article distributed under the terms and conditions of the Creative Commons Attribution license (http://creativecommons.org/licenses/by/4.0/). 